\title{
The Influence of Various Chloride Salts to Reduce Sodium Content on the Quality Parameters of Şalgam (Shalgam): A Traditional Turkish Beverage Based on Black Carrot
}

\author{
Bilal Agirman and Huseyin Erten (iD) \\ Department of Food Engineering, Faculty of Agriculture, Cukurova University, Adana, Turkey \\ Correspondence should be addressed to Huseyin Erten; herten@cu.edu.tr
}

Received 25 January 2018; Revised 13 May 2018; Accepted 21 May 2018; Published 25 June 2018

Academic Editor: Amy Simonne

Copyright (c) 2018 Bilal Agirman and Huseyin Erten. This is an open access article distributed under the Creative Commons Attribution License, which permits unrestricted use, distribution, and reproduction in any medium, provided the original work is properly cited.

\begin{abstract}
Sodium chloride is essential in şalgam processing affecting the flavour and microbiological stability of the final product. However, reduction of sodium salt in şalgam beverage is essential due to consumers' demand for low-sodium foods as well as recommendation of health authorities. $\mathrm{NaCl}$ was replaced both partially and totally by $\mathrm{KCl}$ and $\mathrm{CaCl}_{2}$ in the present study. Experimental design was established to investigate the effects of five different combinations (1.7\% NaCl (control treatment); $0.85 \% \mathrm{NaCl}-0.85 \%$ $\mathrm{KCl} ; 0.85 \% \mathrm{NaCl}-0.85 \% \mathrm{CaCl}_{2} ; 0.85 \% \mathrm{KCl}-0.85 \% \mathrm{CaCl}_{2}$, and $0.56 \% \mathrm{NaCl}-0.56 \% \mathrm{KCl}-0.56 \% \mathrm{CaCl}_{2}$ ) of chloride salts on microbiological, chemical, and sensory qualities of şalgam. Lactic acid bacteria (LAB) were present in populations ranging from 8.0 to $8.61 \log \mathrm{cfu} / \mathrm{mL}$ while total yeasts were 6.89 to $7.12 \log \mathrm{cfu} / \mathrm{mL}$ at the end of the process. The maximum number of LAB was detected in the fermentation employed $\mathrm{NaCl}+\mathrm{KCl}$ salts combination. Regarding the microbiological profile, LAB growth was stimulated significantly in presence of $\mathrm{KCl}$ while yeast patterns were not linked to different salt treatments. The final values of total acidity (TA) and $\mathrm{pH}$ for şalgam were found between 7.40 and $8.71 \mathrm{~g} / \mathrm{L}$ and 3.26-3.47, respectively. Concerning physicochemical attributes, $\mathrm{pH}$ decreased when $\mathrm{CaCl}_{2}$ increased while TA is higher in the presence of $\mathrm{CaCl}_{2}$. Şalgam juice fermented with $0.85 \%$ $\mathrm{NaCl}-0.85 \% \mathrm{KCl}$ mineral salt combination received the best sensory results among the different salt substitutions. Results demonstrate that $\mathrm{NaCl}$ can be replaced in şalgam with $\mathrm{KCl}$ by $50 \%$, without affecting the traditional taste of şalgam in order to meet consumers' demand for low-sodium dietary intake.
\end{abstract}

\section{Introduction}

Şalgam (shalgam) is a traditional beverage specific to Turkey and is produced via lactic acid fermentation. It has a red colour, cloudy appearance, and sour-soft characters obtained via the lactic acid fermentation (LAF) of a mixture including black carrots (Daucus carota ssp. sativus. var. atrorubents Alef.), the main raw material, sourdough, rock salt, bulgur flour (setik), turnips (Brassica rapa L.), and drinkable water $[1,2]$. In recent years, şalgam has begun to be consumed almost all over the country, especially in Istanbul, Ankara, and Izmir and is produced on an industrial scale. In addition, it has been stated that şalgam is currently on sale in markets in some European countries [3].
Lactic acid production is the most important characteristic of LAF products, such as pickles, brine, table olives, kefir, yoghurt, tarhana, and cheese, as lactic acid increases the shelf-life of the products and has a significant effect on their taste. Lactic acid imparts a sour taste to şalgam as well as facilitating digestion, refreshing and regulating the $\mathrm{pH}$ of the digestive system, and giving the body more beneficial use of some minerals [4]. Additionally, pathogenic microorganisms cannot grow at acidic $\mathrm{pH}(\leq 4.5)$ in LAF products, which is beneficial to health [4].

Şalgam is a product manufactured on an industrial scale, and the production process consists of the preparation of raw materials, fermentation, and packaging. There are two different commercial production methods, that is, traditional and direct [5]. The traditional method involves two 
stages; the first stage is the dough fermentation, called the first fermentation, and the second stage is the carrot or main fermentation, known as the second fermentation. The purpose of the first fermentation is enrichment of lactic acid bacteria $(\mathrm{LAB})$ in the fermentation environment. The main difference between the traditional method and direct method is that dough fermentation is not carried out in the direct fermentation $[2,6]$.

The most important raw material in the production of şalgam is the black carrot, which belongs to the Apiaceae (formerly Umbelliferae) family, scientific name Daucus carota $\mathrm{L}$., and is one of the most important root vegetables [7]. There are two kinds of carrot: black and yellow. Black carrots are used in the production of şalgam and belong to the anthocyanin group, which is considered to be the most important natural food colorant. Black carrots are used to produce lactic acid by LAB during sugar fermentation and provide the unique red colour during the production of şalgam [8].

Salt is another important raw material in the production of salgam. Unless otherwise stated, salts means sodium chloride formed by the combination of sodium and chlorine ions [9]. Unrefined rock or sea salt can be used and added at a ratio of $1-2 \%$ during şalgam production. Salt affects the development of pathogenic and degrading microorganisms during fermentation, thus promoting the action of LAB [8].

Salt (sodium chloride) is essential for life; the amount of sodium and chlorine in the body is very important, and many specific mechanisms work in unison to keep them under control [10]. Although common table salt consists of sodium and chloride chemically, sodium can be found in other forms, and daily sodium intake is primarily connected with the culture and dietary habits of a specific population [11]. The sodium mineral can be found both in a variety of natural foods (milk, meat, shellfish, eggs, and soy) or processed foods (breads, crackers, cheese, snack foods, and processed meats) [10].

Some of the important functions of sodium in the human body are helping to regulate the acid-base and water balance in body fluids outside the cell, regulating blood pressure, and absorbing the nutrients in the small intestine, and it is essential for the maintenance of cellular membrane potential and for smooth muscle and nerve functions $[10,12]$. On the contrary, there are some disadvantages in the case of excessive consumption of sodium such as dizziness, vomiting, diarrhoea, and abdominal cramps [13]. The World Health Organization (WHO) reported that increased sodium consumption is associated with increased blood pressure, whereas lower sodium consumption appears to decrease blood pressure in adults [14]. According to the WHO report, increased sodium intake has also been associated with cardiovascular diseases [10, 15-17]. In addition, excessive sodium chloride intake into the body causes water to be withdrawn from the cells, as in order to normalize the sodium, the amount of fluid outside the cell increases. Deterioration of the thirst mechanism or too much water loss, caused by any malfunctioning of water inlet, causes abnormal sodium concentration in the plasma (hypernatraemia). Severe hypernatraemia can lead to bloating, high blood pressure, rapid heartbeat, difficulty breathing, whining, coma, and death [13].

National and international health organizations, consumer organizations, and the industries advise to decrease the sodium level in diet due to some of the negative effects of excessive sodium intake which are listed above. Therefore, reduction of sodium in foods especially in fermented foods has been studied mostly since last three decades. Also, the effect of different mineral salts on the fermentation profile, microbial flora, physicochemical, textural, and flavour characteristics of product was investigated in this context. For instance, substitution of $\mathrm{NaCl}$ was carried out with $\mathrm{KCl}$, $\mathrm{CaCl}_{2}$, and $\mathrm{MgCl}_{2}$ in sauerkraut [18], with monosodium glutamate, $\mathrm{KCl}$, and $\mathrm{CaCl}_{2}$ in olives $[19,20]$ and with $\mathrm{KCl}$ in cheese fermentations [21].

Nowadays, concerns regarding sodium are increasing due to the rising consumption of sodium salt by consumers. In recent years, health-related authorities have recommended that the dietary intake of sodium salt should be reduced due to the association of sodium with hypertension, which is detrimental to public health. WHO strongly recommends that the maximum level of sodium intake should be lesser than $2 \mathrm{~g} /$ day ( $5 \mathrm{~g} /$ day salt) for children and adults [10]. Nevertheless, the typical intake of sodium among adults is $3756 \mathrm{mg} /$ day and for children is $3074 \mathrm{mg} /$ day in the USA [15], whereas sodium intake ranges between 3270 and $4420 \mathrm{mg} /$ day in European countries and is $4100 \mathrm{mg} /$ day in Turkey [16]. The lowest sodium intake was determined to be in Denmark, and the highest value among the Europe Union countries was observed in Italy. Many countries are applying a national nutrition policy to ensure lower salt intake in accordance with European Commission suggestions. One of the most commonly used methods to decrease sodium intake is the utilization of sodium substitutes. Potassium, magnesium, and calcium salts are commonly used to replace sodium chloride in foods. Recent studies report the effect of the combination or sole use of sodium, potassium, calcium, and magnesium salts on fermentation and microbial composition [20, 22-25].

The aims of this study were to reduce the level of sodium chloride in şalgam by using different mineral salts $(\mathrm{KCl}$ and $\mathrm{CaCl}_{2}$ ) and to ascertain the effect of different concentrations of chloride salts on the microbiological, physicochemical, and organoleptic profile of şalgam during the traditional fermentation.

\section{Materials and Methods}

2.1. Experimental Design and Şalgam Production. Black carrots, şalgam turnips, and bulgur flour (setik) were obtained from local markets. Baker's yeast was used for the sourdough preparation. Şalgam was produced using a traditional method described by Erten and Tanguler [4]. In order to reduce the sodium content of şalgam, combinations of sodium chloride $(\mathrm{NaCl})$, potassium chloride $(\mathrm{KCl})$, and calcium chloride $\left(\mathrm{CaCl}_{2}\right)$ were used in the fermentation. The control was the fermentation using only $\mathrm{NaCl}$. Salts were obtained from the Merck Group (Germany). 
Experiments were performed using 5 different salt combinations:

(1) $\mathrm{NaCl}(1.7 \%)$-trial AA (control group)

(2) $\mathrm{NaCl}-\mathrm{KCl}(0.85 \%+0.85 \%)$-trial $\mathrm{BB}$

(3) $\mathrm{NaCl}-\mathrm{CaCl}_{2}(0.85 \%+0.85 \%)$-trial CC

(4) $\mathrm{KCl}-\mathrm{CaCl}_{2}(0.85 \%+0.85 \%)$ - trial DD

(5) $\mathrm{NaCl}-\mathrm{KCl}-\mathrm{CaCl}_{2}(0.56 \%+0.56 \%+0.56 \%)-$ trial EE.

Salgam production was carried out in two stages. During the first stage, the mixture containing 3\% bulgur flour (900 g), $0.2 \%$ different chloride salts $(60 \mathrm{~g})$, and $0.2 \%$ sourdough (obtained by fermenting baker's yeast at room temperature for 24 hours and used as $60 \mathrm{~g}$ ) was kneaded with potable water to form the dough, which were then fermented in a fermentation pouch at $25^{\circ} \mathrm{C}$. The first fermentation was conducted for 4 days, and then the dough was extracted 3 times with water. The total amount of water used in the extraction is 15 litres which represents half volume of the fermentation vessel. The liquid obtained from the first fermentation was transferred into 30 litre plastic drums to start the second fermentation. In addition, $1.5 \%$ of different chloride salts $(450 \mathrm{~g}), 20 \%$ black carrots $(6 \mathrm{~kg})$ (chopped into $3 \mathrm{~cm}$ size pieces), and $2 \%$ şalgam turnips $(600 \mathrm{~g})$ were added to the fermentation vessels. The drums were filled with adequate potable water, and fermentations were carried out at $25^{\circ} \mathrm{C}$ [5]. The amount of whole raw materials was calculated in terms of weight by using percentage (\%) from the total volume of the fermentation vessel. Şalgams were produced in duplicates. Fermentation was monitored by total acid determination, and terminated when there was no increase in the amount of acid. When fermentation was complete, the şalgam turnips and black carrots were removed from the sediment by filtration, and then şalgam juices are bottled and placed in a cold room for sensorial analysis.

\subsection{Enumeration of Microorganisms during Salgam} Fermentation. LAB, total yeasts, non-Saccharomyces yeasts, total mesophilic aerobic bacteria (TMAB), and coliform bacteria were enumerated at the beginning and end of the dough fermentation, as well as in the liquid obtained from the extraction stage. Similarly, the same microorganisms described above were counted every 2 days during the şalgam fermentation. During the dough fermentation, $10 \mathrm{~g}$ of dough was dispersed aseptically into $90 \mathrm{~mL}$ of sterile physiological saline $(8.5 \mathrm{~g} / \mathrm{L})$ and mixed thoroughly. During the course of the second (main) fermentation, $100 \mathrm{~mL}$ șalgam samples were taken from the fermentation vessel after the tank contents were mixed to ensure homogenization. Salgam samples were serially diluted in physiological saline solution, and $0.1 \mathrm{~mL}$ of the diluted samples were spread onto plates of MRS (de Man, Rogosa and Sharpe) agar and M17 agar (Merck, Germany) supplemented with $50 \mathrm{mg} / \mathrm{L}$ cycloheximide (Sigma-Aldrich, Germany) to prevent the growth of yeasts and moulds. Plates were incubated at $30^{\circ} \mathrm{C}$ for 3-5 days in jars which included Anaerocult A (Merck KGaA, Germany) to supply an anaerobic environment for LAB $[26,27]$.
In order to determine the number of serially diluted yeasts, şalgam samples were inoculated onto Malt Extract Agar (Merck, Germany) supplemented with $100 \mathrm{mg} / \mathrm{L}$ oxytetracycline (Sigma-Aldrich, Germany) to prevent the growth of bacteria. L-lysine agar (Sigma-Aldrich, Germany) was used to enumerate non-Saccharomyces yeasts. Malt Extract Agar and L-lysine agar plates were incubated at $25^{\circ} \mathrm{C}$ for 3-5 days. TMAB and coliform bacteria were counted on plate count agar (PCA) and violet red bile agar (VRBA), respectively. PCA plate incubations were conducted at $30^{\circ} \mathrm{C}$ for 3 days, and VRBA plates were incubated at $37^{\circ} \mathrm{C}$ for 48 hours $[28,29]$.

2.3. Chemical Measurements. The $\mathrm{pH}$ of the şalgams was measured at 2-day intervals during fermentation using a digital $\mathrm{pH}$ meter (Mettler Toledo $\mathrm{pH}$ Ion/S220, Switzerland). Total acidity was determined by titrating şalgam samples up to $\mathrm{pH} 8.2$ using $0.1 \mathrm{~N} \mathrm{NaOH}$ and is expressed in terms of lactic acid per $\mathrm{g} / \mathrm{L}$ according to the TS EN 12147 [30]. Salt concentrations were determined by titrating $0.1 \mathrm{~N} \mathrm{AgNO}_{3}$ according to the Mohr method and are expressed as a percentage (\%) of $\mathrm{NaCl}$ [31]. The method recommended by the AOAC was used for total dry matter and ash analysis. A Venticell 222 brand ventilated oven and Protherm PLF 11 0/15 model ash furnace were used to determine the total dry matter and ash ratios of salgams, respectively. The total sugar content of şalgams was determined using the phenol-sulfuric acid method according to Amrane and Prigent [32]. Reducing sugar was detected via the DNS method used by Ghose [33]. Volatile acidity was determined using the steam distillation method, and results are given as acetic acid in $\mathrm{g} / \mathrm{L}$ [34].

2.4. Sensory and Principal Component Analysis (PCA). The sensory evaluation of şalgams produced with different chloride salts was performed using the scoring and ranking (preference) test according to Barillere and Benard [35]. The scoring test was performed on a scale of 10 points, indicating colour, odour, taste, acidity (sourness), saltiness, bitterness (coming from different chloride salts), swallowing character, and finally, general acceptability. Panelists subsequently graded the most preferred şalgam through to the least preferred using the ranking test. Sensory analysis was performed by 15 expert panelists.

PCA was applied to the results obtained from the evaluation of sensory analysis. Pearson $(n-1)$ PCA type was applied using the XLSTAT 4.06 program; hence, the correlation relationship between variables involved in sensory analysis was determined, and the interaction between the variables was clarified. Additionally, a biplot graph was created by determining the factor components of both the experiments involving different chloride salts and variables used in the sensory analysis. A biplot is a visualization technique for PCA, and biplot simply means a plot of two spaces: the subject and variable spaces. Biplot analysis is a widely used method because it enables displaying large data matrices of many variable lines and columns as a simple graphic [36]. 
TAвLE 1: Number of microorganisms during the dough fermentation and in the extraction liquid.

\begin{tabular}{|c|c|c|c|c|c|c|c|c|c|c|c|c|c|c|c|}
\hline \multirow{4}{*}{$\begin{array}{l}\text { Experiments } \\
\text { Days }\end{array}$} & \multicolumn{10}{|c|}{ Dough fermentation } & \multirow{2}{*}{\multicolumn{5}{|c|}{$\begin{array}{c}\text { Extraction liquid } \\
\text { Number of microorganisms } \\
(\log \mathrm{cfu} / \mathrm{mL})\end{array}$}} \\
\hline & \multicolumn{10}{|c|}{ Number of microorganisms $(\log \mathrm{cfu} / \mathrm{mL})$} & & & & & \\
\hline & \multicolumn{2}{|c|}{ AA } & \multicolumn{2}{|c|}{$\mathrm{BB}$} & \multicolumn{2}{|c|}{$\mathrm{CC}$} & \multicolumn{2}{|c|}{$\mathrm{DD}$} & \multicolumn{2}{|c|}{$\mathrm{EE}$} & $\mathrm{AA}$ & $\mathrm{BB}$ & $\mathrm{CC}$ & DD & $\mathrm{EE}$ \\
\hline & Day 0 & Day 4 & Day 0 & Day 4 & Day 0 & Day 4 & Day 0 & Day 4 & Day 0 & Day 4 & & & & & \\
\hline Microorganisms & & & & & & & & & & & & & & & \\
\hline LAB & 8.56 & 10.36 & 8.45 & 10.27 & 8.73 & 10.47 & 8.60 & 10.50 & 8.58 & 10.39 & 9.27 & 9.56 & 9.31 & 9.0 & 8.92 \\
\hline TMAB & 8.57 & 10.11 & 8.63 & 10.18 & 8.55 & 10.10 & 8.34 & 9.97 & 8.44 & 10.08 & 8.97 & 9.91 & 9.06 & 7.9 & 9.11 \\
\hline Total yeasts & 8.56 & 9.81 & 8.53 & 9.90 & 8.43 & 9.78 & 8.33 & 9.70 & 8.51 & 9.77 & 8.47 & 8.92 & 8.54 & 8.65 & 8.69 \\
\hline Non-Saccharomyces yeasts & 6.60 & 9.77 & 6.45 & 9.68 & 6.80 & 9.75 & 6.48 & 9.35 & 6.53 & 9.70 & 7.87 & 8.60 & 8.39 & 8.39 & 8.54 \\
\hline Coliform bacteria & 4.47 & 5.0 & 3.80 & 4.50 & 3.70 & 4.48 & 3.65 & 4.24 & 4.52 & 4.84 & n.d. & n.d. & n.d. & n.d. & n.d. \\
\hline
\end{tabular}

AA: şalgam produced with $\mathrm{NaCl}$; $\mathrm{BB}$ : şalgam produced with $\mathrm{NaCl}+\mathrm{KCI}$; CC: şalgam produced with $\mathrm{NaCl}+\mathrm{CaCl}_{2} ; \mathrm{DD}$ : şalgam produced with $\mathrm{KCl}+\mathrm{CaCl}{ }_{2}$; EE: şalgam produced with $\mathrm{NaCl}+\mathrm{KCl}+\mathrm{CaCl}_{2}$. LAB: lactic acid bacteria; TMAB: total mesophilic aerobic bacteria.

2.5. Statistical Analysis. Results obtained from the laboratory studies were compared by one-way analysis of variance (ANOVA) using the software SPSS 20.0, and the Duncan multiple comparison test was applied to significant differences. The level of significance was assessed as $p=0.05$ [37].

\section{Results and Discussion}

3.1. Fermentation and Microbiology Results. The carrot (main) fermentation of the şalgam beverage is naturally completed between 3 and 10 days at temperatures ranging from 10 to $35^{\circ} \mathrm{C}$ [4]. In this study, the dough and carrot fermentations were completed in 4 and 8 days during the production of şalgam with different chloride salts, respectively.

Counts of LAB, TMAB, total yeasts, non-Saccharomyces yeasts, and coliform bacteria were between 8.45 and $8.73 \mathrm{log}$ $\mathrm{cfu} / \mathrm{mL}, 8.34$ and $8.63 \log \mathrm{cfu} / \mathrm{mL}, 8.33$ and $8.56 \log \mathrm{cfu} / \mathrm{mL}$, 6.45 and $6.80 \log \mathrm{cfu} / \mathrm{mL}$, and 3.65 and $4.52 \log \mathrm{cfu} / \mathrm{mL}$ at the beginning of the dough fermentation. It was observed that the total number of microorganisms examined increased during the course of the dough fermentation (Table 1). Therefore, the number of LAB, TMAB, total yeasts, nonSaccharomyces yeasts, and coliform bacteria scaled up to 10.27-10.50 log cfu/mL, 9.97-10.18 log cfu/mL, 9.70$9.90 \log \mathrm{cfu} / \mathrm{mL}, 9.35-9.77 \log \mathrm{cfu} / \mathrm{mL}$, and $4.24-5.00 \log$ $\mathrm{cfu} / \mathrm{mL}$, respectively, at the end of the first fermentation. The rapid increase in microbial numbers is thought to be due to the high level of nutrients in the setik, which is the main raw material in the dough fermentation and the quick adaption of microorganisms to the fermentation environment. It has been reported that the total sugar content of setik, including starch, ranges from 46.4 to $91.4 \mathrm{~g} / \mathrm{kg}$ [38]. Similarly, a high $\mathrm{LAB}$ number has also been reported in other studies, such as Utus [39] and Tanguler [38], who found that total LAB levels ranged from 6.97 to $8.00 \log \mathrm{cfu} / \mathrm{mL}$ from day 0 to the end of the first fermentation.

As soon as the first fermentation was complete, the fermented mixtures were extracted 3 times with adequate water in order to ensure the passage of proliferated microorganisms into the water to be used in the carrot fermentations. Although there was a slight decrease in the microbial (LAB, TMAB, total yeasts, and non-Saccharomyces yeasts) counts determined in the extraction liquid, compared with the dough fermentation, high numbers of LAB, TMAB, total yeasts, and non-Saccharomyces yeasts were detected in the extraction liquid (Table 1). Conversely, coliform bacteria were not determined in the medium. It is quite difficult to transfer all the microorganisms present in the dough into the extraction water, and for this reason, there was a small decline in the numbers of microorganisms enumerated from the extraction liquid. As a result, increasing the number of repetitions of the extraction process could lead to an increase in the transfer of microorganisms from the dough to the extraction water. Extraction liquids were rich in terms of LAB and yeasts, which are mainly responsible for natural şalgam fermentations. The lowest and highest LAB and total yeast numbers were between 8.92 and $9.56 \log \mathrm{cfu} / \mathrm{mL}$ and $8.47-8.92 \log \mathrm{cfu} / \mathrm{mL}$ in the extraction liquid, respectively. The results obtained show that there was no noticeable difference, with regard to microbial numbers, between different chloride salt trials during dough fermentation, because different chloride salts were used in small quantities $(0.2 \% \mathrm{w} / \mathrm{v})$ in the dough fermentation. Tanguler and Erten [6] reported that the viable population of $\mathrm{LAB}$ was $7.37 \log \mathrm{cfu} / \mathrm{mL}$ in the extract after combining with the raw materials and adequate water for the second fermentation.

Samples from the şalgam produced using different chloride salts were taken every 2 days from the first day to the end of the carrot fermentation. Numbers of LAB, TMAB, total yeasts, non-Saccharomyces yeasts, and coliform bacteria were enumerated on a specific medium for each sampling. Microbial development is shown in Figure 1, and the microbiological analytical results are in good agreement with other studies $[3,5,6]$. Results indicate that $\mathrm{LAB}$ were the predominant microflora in şalgam fermentations for all trials. The occurrence of LAB could stem from the surfaces of the raw materials and fermentation vessels and from the sourdough extract. $L b$. plantarum is reported as the main LAB species driving şalgam fermentation. In addition, $L b$. casei, $L b$. brevis, $L b$. buchneri, Lactococcus lactis, Leuconostoc mesenteroides, and Pediococcus pentosaceus species constitute the fermentation microbiota of the şalgam beverage [5].

The number of LAB was determined to be 8.96-9.19log $\mathrm{cfu} / \mathrm{mL}$ at the beginning of the fermentation (Figure 1(a)). The LAB count increased until the second day of the 


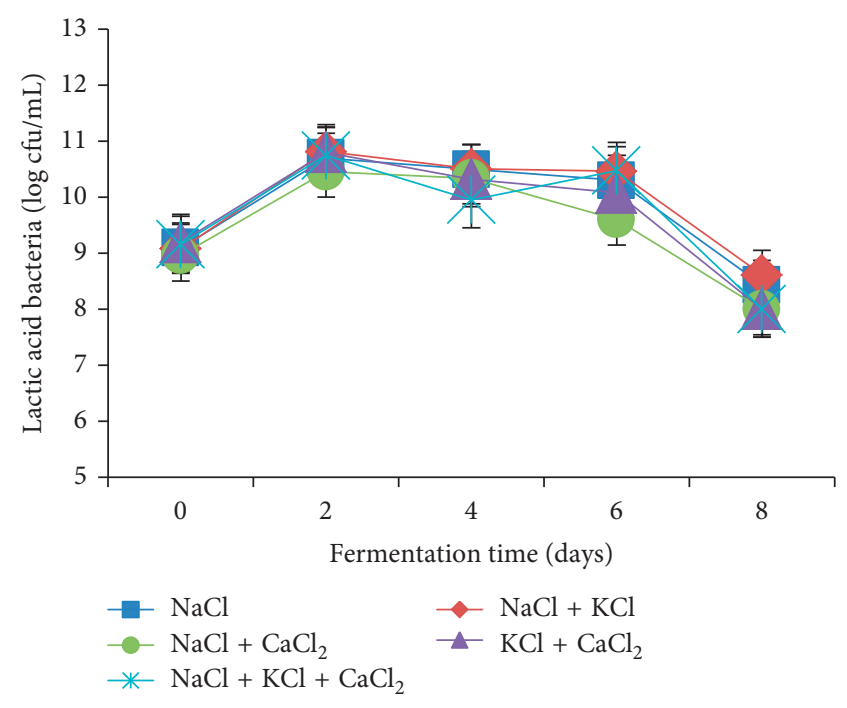

(a)

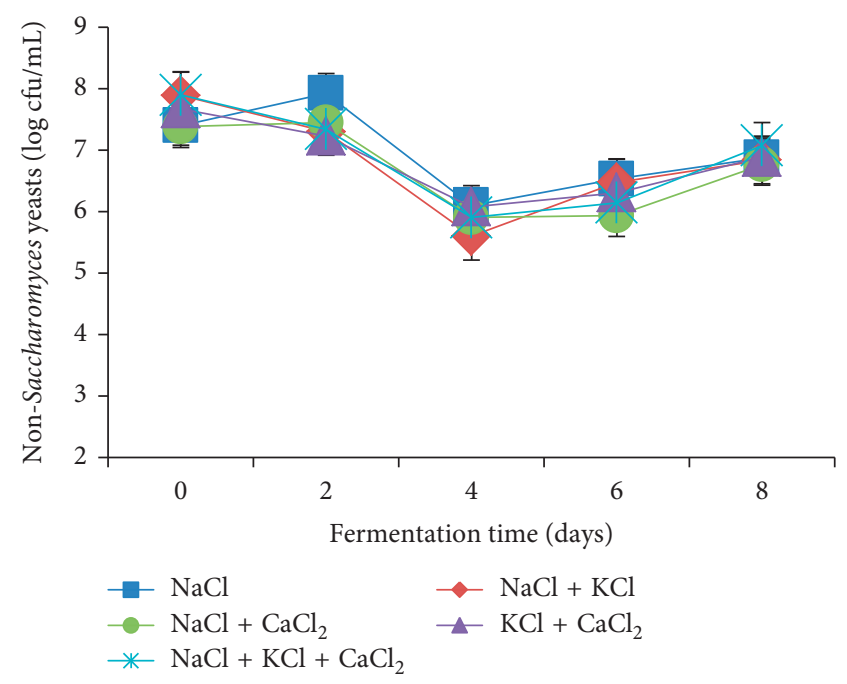

(c)

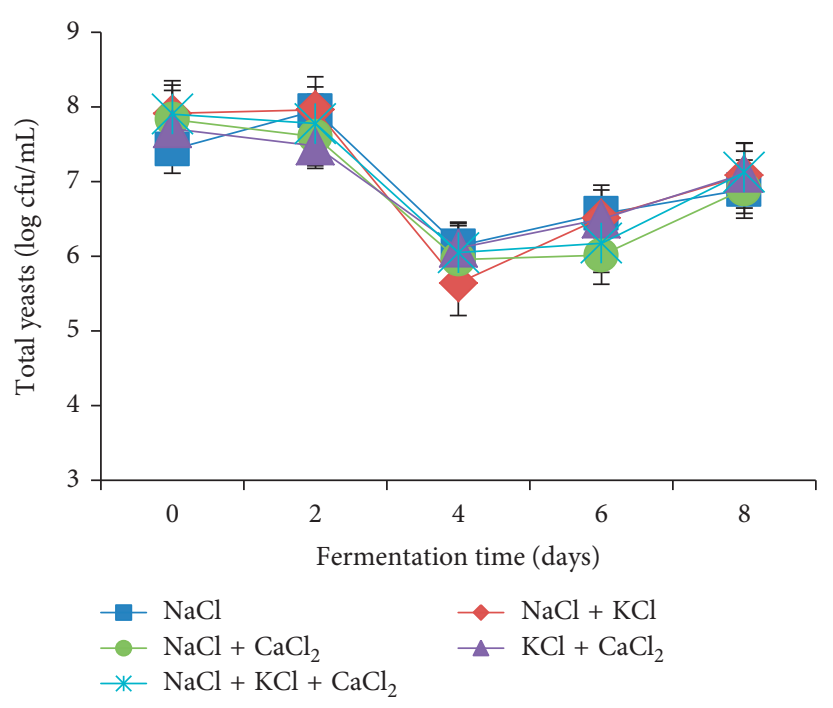

(b)

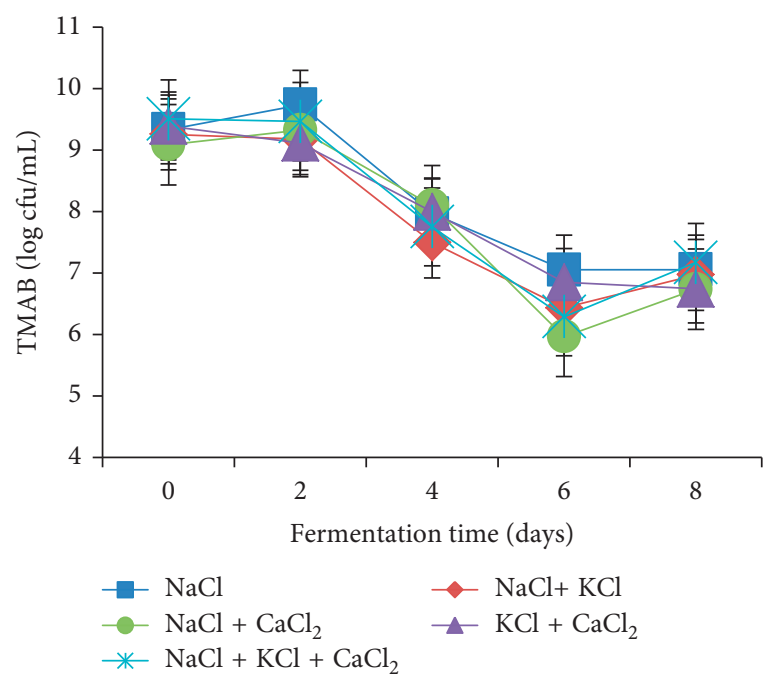

(d)

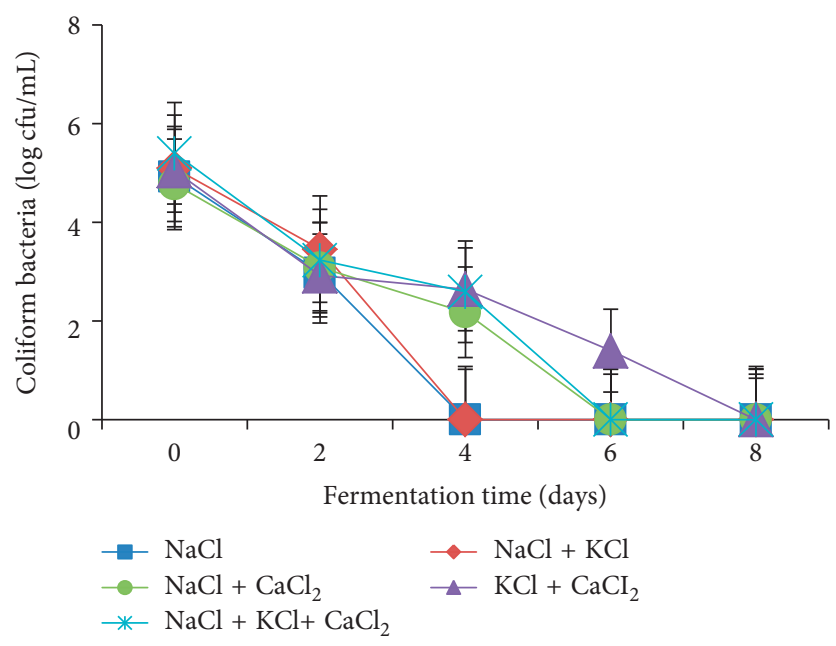

(e)

Figure 1: The development of microorganisms during the şalgam fermentations produced using different chloride salts. (a) Development of LAB, (b) development of total yeasts, (c) development of non-Saccharomyces yeasts, (d) development of TMAB, and (e) development of coliform bacteria. 
TABLE 2: Number of microorganisms as logarithmic cfu/mL at the end of the şalgam fermentation.

\begin{tabular}{lccrr}
\hline & & Number of microorganisms & & \\
Experiments & LAB & Total yeasts & Non-Saccharomyces yeasts & TMAB \\
\hline $\mathrm{NaCl}$ & $8.43 \pm 0.021^{\mathrm{b}}$ & $6.89 \pm 0.268$ & $6.87 \pm 0.424$ & $7.05 \pm 0.417$ \\
$\mathrm{NaCl}+\mathrm{KCl}$ & $8.61 \pm 0.014^{\mathrm{a}}$ & $7.08 \pm 0.346$ & $6.83 \pm 0.106$ & $6.96 \pm 0.007$ \\
$\mathrm{NaCl}+\mathrm{CaCl} 2$ & $8.00 \pm 0.339^{\mathrm{c}}$ & $6.90 \pm 0.042$ & $6.76 \pm 0.014$ & $6.73 \pm 0.001$ \\
$\mathrm{KCl}+\mathrm{CaCl}_{2}$ & $8.00 \pm 0.001^{\mathrm{c}}$ & $7.10 \pm 0.042$ & $6.88 \pm 0.166$ & $6.74 \pm 0.007$ \\
$\mathrm{NaCl}+\mathrm{KCl}+\mathrm{CaCl}_{2}$ & $8.00 \pm 0.120^{\mathrm{c}}$ & $7.12 \pm 0.445$ & $7.07 \pm 0.579$ & $7.17 \pm 0.261$ \\
\hline
\end{tabular}

Values with different superscripts in the same column indicate statistically significant differences $(p<0.05)$. LAB: lactic acid bacteria; TMAB: total mesophilic aerobic bacteria.

fermentation, for all experiments, and then there was a slight decrease until the end of the fermentation for all trials except experiment $\mathrm{EE}$, which included all salts in a combination of equal ratio. A slight increase was observed on the 6th day of fermentation for LAB numbers, and after day 6 , a decrease was observed in experiment EE. Şalgams produced with different chloride salts contained 8.0-8.61 log cfu/mL LAB at the end of fermentation. The highest number of LAB was detected in treatment $\mathrm{BB}$ at the end of the fermentation, and it was ascertained that the utilization of $\mathrm{KCl}$ in şalgam fermentation led to a significant increase $(p<0.05)$ in the number of LAB (Table 2). The LAB population determined in this study was slightly higher than the results of Tanguler and Erten [3], Tanguler et al. [5], and Utus [39] who found the last counts of LAB to be in the range of 7.30-8.23 log $\mathrm{cfu} / \mathrm{mL}$ at the end of the şalgam fermentations produced using the traditional method. After evaluating LAB counts, it can be concluded that using the $\mathrm{KCl}$ salt in şalgam production positively affected the development of LAB.

Changes in total yeast count are shown in Figure 1(b). The total number of yeasts varied from 7.43 to $7.91 \mathrm{log}$ $\mathrm{cfu} / \mathrm{mL}$ at the beginning of the carrot fermentation. The total yeast numbers decreased between the start of fermentation and the second day for all experiments except the control and experiment $\mathrm{BB}$, while total yeast numbers decreased from the second to the fourth day for all experiments. The total number of yeasts subsequently increased until the 8th day, that is, fermentation completion. While the highest total yeast number from all trials was $7.96 \log \mathrm{cfu} / \mathrm{mL}$ in the $\mathrm{BB}$ sample after 2 days of fermentation, the total yeasts on plates ranged from 6.89 to $7.12 \log \mathrm{cfu} / \mathrm{mL}$ at the end of fermentation. The lowest number of yeasts throughout the fermentation was determined on day four for all experiments. The sample containing the lowest number of yeasts at the end of fermentation was AA, while the highest was EE. Similar results were obtained in other studies on șalgam where the total yeast numbers were determined to be between 6.96 and $7.60 \log \mathrm{cfu} / \mathrm{mL}[38,39]$. It was revealed that the use of sodium, potassium, and calcium salts in the production of şalgam does not have a negative effect on yeast or LAB growth. Similarly, in another study, on the fermentation profile of Spanish-style Manzanilla olives, Bautista-Gallego et al. [20] investigated the effect of the partial replacement of sodium chloride with potassium and calcium chloride and noticed that there was no significant relationship between the concentrations of different salt mixtures and yeast population.
The non-Saccharomyces yeasts enumerated on L-lysine agar and growth lines are shown in Figure 1(c). Initially, the number of non-Saccharomyces yeasts ranged from 7.38 to $7.89 \log \mathrm{cfu} / \mathrm{mL}$ and decreased to $6.76-7.07 \log \mathrm{cfu} / \mathrm{mL}$ at the end of the fermentations. The lowest and highest numbers of non-Saccharomyces yeasts were counted in samples obtained from trials CC and EE at the end of fermentation, respectively. There was a decrease in the number of nonSaccharomyces yeasts between the second and fourth day of fermentation, and after that an increase occurred until the fermentations were completed for all experiments. Tanguler [38] and Utus [39] reported the highest number of nonSaccharomyces yeasts as $5.19 \log \mathrm{cfu} / \mathrm{mL}$ and $6.46 \log \mathrm{cfu} / \mathrm{mL}$ at the end of fermentation, respectively. It is noticeable from the growth curve (Figure 1(c)) that non-Saccharomyces yeast counts in şalgam produced using different chloride salts were fairly close to each other and higher than the values reported in other studies.

The TMAB count was determined to be $9.08-9.50 \mathrm{log}$ $\mathrm{cfu} / \mathrm{mL}$ in samples CC and EE at the beginning of fermentation, while the counts were between 6.73 and $7.17 \mathrm{log}$ $\mathrm{cfu} / \mathrm{mL}$ in samples CC and EE at the end of the carrot fermentation, respectively (Figure $1(\mathrm{~d})$ ). Even though a decline was observed from the second to the sixth day of the fermentation in terms of TMAB counts, a rise was then seen in all treatments until the fermentations were terminated. The results are in good agreement with previous studies of Tanguler and Erten [3], Utus [39], and Arici [40] who found the final counts of TMAB to be in the range of 5.90-7.79 log $\mathrm{cfu} / \mathrm{mL}$. However, the number of TMAB determined in this study was higher than the maximum value of $5 \log \mathrm{cfu} / \mathrm{mL}$ specified by the Turkish Şalgam Standard TS 11149 [30].

As a result of the analysis, the numbers of coliform bacteria were found to be between 4.77 and $5.39 \log \mathrm{cfu} / \mathrm{mL}$ initially, and then decreased during fermentations and were not detected at the end of the fermentations for all experiments. Due to the quick $\mathrm{pH}$ drop, coliform bacteria died off in the şalgam fermentations [41]. Coliform bacteria were not determined on the fourth day of fermentation for $\mathrm{AA}$ and $\mathrm{BB}$ samples, on the sixth day for CC and EE samples, and finally, they were not found on the last day of fermentation for experiment DD (Figure 1(e)).

3.2. Chemical Composition of Şalgam. The main end product of şalgam fermentation is lactic acid, which is the source of the sour character and is produced via LAB during șalgam 


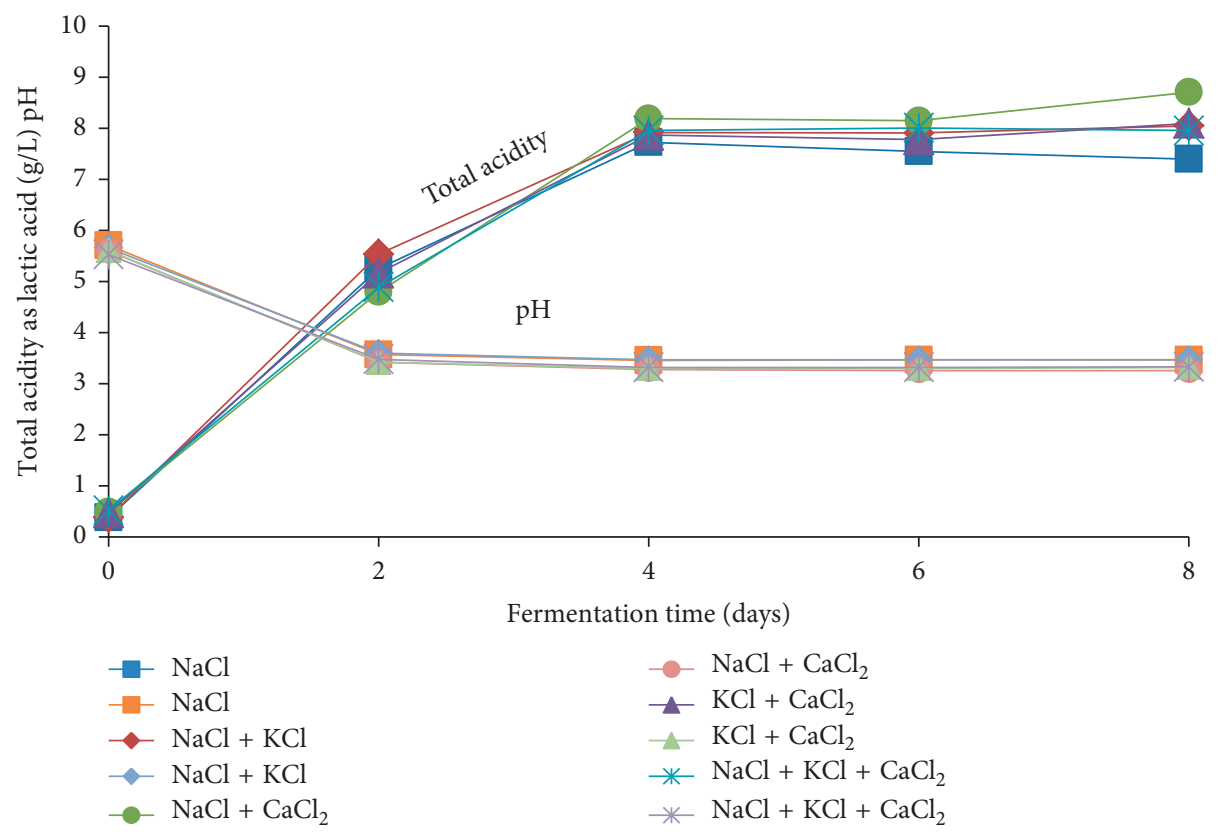

FIgURE 2: The development of total acidity as lactic acid and $\mathrm{pH}$ during the fermentation of şalgams produced using different chloride salts.

TABLE 3: Chemical composition of şalgam produced with different chloride salts.

\begin{tabular}{|c|c|c|c|c|c|c|}
\hline \multicolumn{7}{|c|}{ Experiments } \\
\hline Chemical properties & AA & BB & CC & $\mathrm{DD}$ & $\mathrm{EE}$ & S \\
\hline${\text { Total } \text { acidity }^{1}(\mathrm{~g} / \mathrm{L})}$ & $7.40 \pm 0.19^{c}$ & $8.05 \pm 0.19^{b}$ & $8.71 \pm 0.06^{\mathrm{a}}$ & $8.10 \pm 0.39^{\mathrm{ab}}$ & $7.96 \pm 0.19^{\mathrm{bc}}$ & $*$ \\
\hline $\mathrm{pH}$ & $3.47 \pm 0.021^{\mathrm{a}}$ & $3.47 \pm 0.00^{\mathrm{a}}$ & $3.26 \pm 0.007^{\mathrm{c}}$ & $3.32 \pm 0.021^{\mathrm{b}}$ & $3.33 \pm 0.007^{\mathrm{b}}$ & $*$ \\
\hline Salt (\%) & $1.57 \pm 0.070$ & $1.50 \pm 0.042$ & $1.54 \pm 0.091$ & $1.61 \pm 0.014$ & $1.59 \pm 0.007$ & ns \\
\hline Dry matter $(g / L)$ & $26.98 \pm 0.328^{c}$ & $26.77 \pm 0.009^{c}$ & $29.89 \pm 0.171^{b}$ & $32.37 \pm 0.165^{\mathrm{a}}$ & $29.38 \pm 0.511^{\mathrm{b}}$ & $*$ \\
\hline Ash $(\mathrm{g} / \mathrm{L})$ & $17.97 \pm 0.438$ & $18.37 \pm 0.240$ & $17.76 \pm 0.509$ & $18.06 \pm 3.903$ & $18.95 \pm 0.212$ & ns \\
\hline Total sugar (g/L) & $0.77 \pm 0.219$ & $0.61 \pm 0.438$ & $0.99 \pm 0.325$ & $0.84 \pm 0.763$ & $0.77 \pm 0.219$ & ns \\
\hline Reducing sugar (g/L) & $0.38 \pm 0.113$ & $0.15 \pm 0.00$ & $0.15 \pm 0.00$ & $0.22 \pm 0.106$ & $0.38 \pm 0.113$ & ns \\
\hline Volatile acidity $^{2}(\mathrm{~g} / \mathrm{L})$ & $0.31 \pm 0.007$ & $0.37 \pm 0.021$ & $0.39 \pm 0.091$ & $0.36 \pm 0.091$ & $0.37 \pm 0.056$ & $\mathrm{~ns}$ \\
\hline
\end{tabular}

Values with different superscripts indicate statistically significant differences. ${ }^{1}$ As lactic acid; ${ }^{2}$ as acetic acid; S: significance; ns: not significant. ${ }^{*}$ Significance at $5 \%$ by LSD (least significant difference). AA: şalgam produced with $\mathrm{NaCl} ; \mathrm{BB}$ : şalgam produced with $\mathrm{NaCl}+\mathrm{KCl} ; \mathrm{CC}$ : şalgam produced with $\mathrm{NaCl}+\mathrm{CaCl}{ }_{2}$; DD: şalgam produced with $\mathrm{KCl}+\mathrm{CaCl}_{2}$; EE: şalgam produced with $\mathrm{NaCl}+\mathrm{KCl}+\mathrm{CaCl}_{2}$.

fermentation [8]. The acidity level of şalgam juice is one of the most important criteria affecting consumer choice. The titratable acidity should be at least $6 \mathrm{~g} / \mathrm{L}$ for lactic acid, and the $\mathrm{pH}$ should be a maximum of 3.8 according to the Turkish Şalgam Standard TS 11149 [30]. The level of total acidity expressed as lactic acid, and $\mathrm{pH}$ values of şalgam produced using different chloride salts was between 0.38 and $0.52 \mathrm{~g} / \mathrm{L}$ and 5.53-5.71 at the beginning of the fermentation, respectively. Shortly after the fermentations started, the acidity levels quickly increased while the $\mathrm{pH}$ values decreased (Figure 2). The titratable acidity as lactic acid and $\mathrm{pH}$ level were determined to be $7.4-8.71 \mathrm{~g} / \mathrm{L}$ and $3.26-3.47$ for end products, respectively. Furthermore, the şalgam which had the lowest $\mathrm{pH}$ and highest acidity content was produced by treatment $\mathrm{CC}$. In addition, the highest $\mathrm{pH}$ level was detected in şalgam $\mathrm{AA}$ and $\mathrm{BB}$ which exhibited equal $\mathrm{pH}$ values, while the lowest acidity level was determined in şalgam AA (control experiment). The results obtained show that the level of total acidity and $\mathrm{pH}$ of whole şalgam juices were within the values given in the Turkish Şalgam Standard. Tanguler et al. [5] determined the highest total acidity as $9.22 \mathrm{~g} / \mathrm{L}$ in şalgam, which was produced by the addition of Lactobacillus ( $L b$.) plantarum as a starter culture, whereas the lowest amount was found to be $6.33 \mathrm{~g} / \mathrm{L}$ in şalgam produced by the direct method. The differences between the $\mathrm{pH}$ and acidity levels of şalgam produced using different chloride salts were statistically significant $(p<0.05)$ (Table 3). Considering that the lowest acidity and the highest $\mathrm{pH}$ values were found when using the $\mathrm{NaCl}$ salt alone, it can be said that other chloride salts ( $\mathrm{K}$ and $\mathrm{Ca}$ ) contribute to the formation of lactic acid during şalgam fermentation.

The salt content varied from 15.00 to $16.10 \mathrm{~g} / \mathrm{L}$ in şalgam produced in this study (Table 3). The revised Turkish Şalgam Standard [30] permits up to $1.7 \%$ salt in şalgam. The highest and lowest salt content was found to be $1.50 \%$ and $1.61 \%$ in terms of $\mathrm{NaCl}$ in samples $\mathrm{BB}$ and $\mathrm{DD}$, respectively. In the present study, the sodium ratio in şalgam was reduced by at least $50 \%$ by replacing $\mathrm{NaCl}$ with $\mathrm{KCl}$ and $\mathrm{CaCl}_{2}$. Moreover, 
şalgam production was carried out without $\mathrm{NaCl}$ in treatment DD. The difference between salt ratios was insignificant according to an analysis of variance (Table 3 ).

Ash is the sum of nonburning substances. These materials are anionic and cationic ions in the inorganic structure and arise from salt used in production, the raw materials, and minerals found in water such as sodium, potassium, calcium, magnesium, iron, and aluminium. The lowest and highest ash content of şalgam juices were found to be between 17.76 and $18.95 \mathrm{~g} / \mathrm{L}$ in samples CC and EE, respectively (Table 3 ). The difference between the amount of ash in the samples was statistically insignificant $(p>0.05)$. An ash ratio of $5.74-22.3 \mathrm{~g} / \mathrm{L}$ has been reported in other studies $[8,38,42]$. Dry matter is the sum of the remaining substances after removing water and other volatile materials from şalgam. Dry matter contains organic acids, salt, protein, colour, and mineral substances. The minimum and maximum dry matter quantity of şalgam ranged from 26.77 to $32.37 \mathrm{~g} / \mathrm{L}$ in samples $\mathrm{BB}$ and $\mathrm{DD}$, respectively (Table 3). On the contrary, the difference between the varying production method, in terms of dry matter content, was significant at the $5 \%$ significance level $(p<0.05)$. The amount of dry matter in another study focusing on şalgam was determined to be $16.9-33.9 \mathrm{~g} / \mathrm{L}[38,39]$. The dry matter results obtained from şalgam produced using different chloride salts are among the values reported by other researchers.

The total sugar and reducing sugar content of samples was determined to be $0.61-0.99 \mathrm{~g} / \mathrm{L}$ and $0.15-0.38 \mathrm{~g} / \mathrm{L}$, respectively (Table 3 ). The difference between şalgam samples produced using different chloride salts in terms of total and reducing sugar was statistically insignificant $(p>0.05)$. The low amount of reducing sugars indicates that lactic acid fermentation was successfully completed. Tanguler [38] and Tanguler et al. [41] reported the total sugar and reducing sugar level of şalgam to be between 0.50 and $0.82 \mathrm{~g} / \mathrm{L}$ and $11.0-14.1 \mathrm{mg} / \mathrm{L}$ at the end of fermentation, respectively.

The amount of volatile acidity changed between 0.31 and $0.39 \mathrm{~g} / \mathrm{L}$ as acetic acid in şalgam produced using different salts and differences was not found to be significant statistically $(p>0.05)$. The results of volatile acidity analysis were in accordance with the Turkish Şalgam Standard, which states that the maximum amount of volatile acidity should be $1 \mathrm{~g}$ per litre as acetic acid. Tanguler et al. [41] reported the volatile acidity content of şalgam as acetic acid to be between 0.69 and $0.80 \mathrm{~g} / \mathrm{L}$.

3.3. Results of Sensory and PCA Analysis. The effect of the usage of different chloride salts on the sensory properties of şalgam was investigated. Şalgams produced using different chloride salts were evaluated in terms of colour, odour, taste, sourness, saltiness, bitterness (coming from different chloride salts), swallowing character, and general acceptability by 15 expert assessors. The results are given in Figure 3.

All şalgams produced using different salts had close scores for colour, while the highest was trial BB, which included sodium and potassium salts. In terms of odour, all şalgams were acceptable and experiment EE was found to have the highest score. There were significant differences

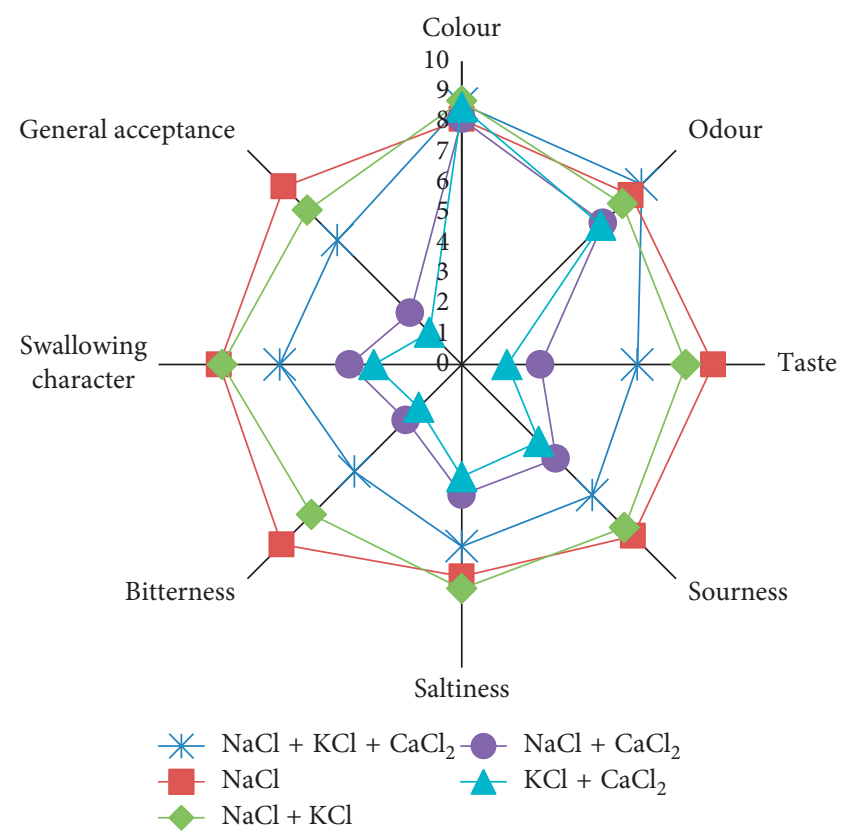

FIgURE 3: Appearance of the results of sensory analysis as a spider web diagram.

when taste results were examined. Ranking of the most preferred şalgam to the least preferred, in terms of taste, in order was $\mathrm{AA}, \mathrm{BB}, \mathrm{EE}, \mathrm{CC}$, and DD. It is remarkable that the most appreciated şalgam was the control group; however, the least favoured was the trial which did not contain the sodium salt. It is considered that the reason for this result is mainly due to the fact that the community is used to consuming sodium salts in their daily diet and is foreign to the flavour of the foods which contain other salts $(\mathrm{KCl}$ and $\mathrm{CaCl}_{2}$ ). The most favoured şalgam for both acidity and bitterness properties were $\mathrm{AA}$ and $\mathrm{BB}$, respectively. The panellists noted that şalgam containing $\mathrm{CaCl}_{2}$ had a rather bitter taste, which limited the organoleptic acceptability. Moreover, şalgam BB was the most appreciated, followed by AA according to salinity, which is the main topic of the research. As in other characteristics, AA and BB şalgams had the highest score in swallowing character. Similar sensory results were obtained in the study examining the impact of different mixtures of $\mathrm{NaCl}, \mathrm{KCl}$, and $\mathrm{CaCl}_{2}$ on the fermentation profiles of Conserveloa natural black olives [24]. Results showed that table olives produced using $\mathrm{CaCl}_{2}$ received high scores in terms of bitterness and were not finally accepted by the panellists. The results of this study are comparable with Panagou et al. [24] and Marsilio et al. [43] who recommended that a combination of equal proportions of $\mathrm{NaCl}+\mathrm{KCl}$ could produce table olives with lower sodium content and good organoleptic characters.

The mean values of all scores given to each property of the sensory analysis evaluation were calculated, and PCA analysis was performed by entering the obtained data into the XL-Stat 4.06 software. The matrix of the correlation between the variables is given in Table 4 . As can be seen from the results, colour and smell variables did not show a close correlation with other variables. Therefore, it can be said that 
TABLE 4: Correlation matrix between variables used in sensory analysis.

\begin{tabular}{lcccccccc}
\hline Variables & Colour & Odour & Taste & Sourness (acidity) & Saltiness & Bitterness & Swallowing character & General acceptance \\
\hline Colour & $\mathbf{1}$ & 0.300 & 0.085 & 0.078 & 0.209 & 0.012 & 0.138 & 0.088 \\
Odour & 0.300 & $\mathbf{1}$ & 0.793 & 0.739 & 0.742 & 0.718 & 0.736 & $\mathbf{0 . 7 9 8}$ \\
Taste & 0.085 & 0.793 & $\mathbf{1}$ & $\mathbf{0 . 9 9 6}$ & $\mathbf{0 . 9 8 3}$ & $\mathbf{0 . 9 8 8}$ & $\mathbf{0 . 9 9 2}$ & $\mathbf{0 . 9 9}$ \\
Sourness (acidity) & 0.078 & 0.739 & $\mathbf{0 . 9 9 6}$ & $\mathbf{1}$ & $\mathbf{0 . 9 8 9}$ & $\mathbf{0 . 9 9 1}$ & $\mathbf{0 . 9 0}$ & $\mathbf{0 . 9 9 4}$ \\
Saltiness & 0.209 & 0.742 & $\mathbf{0 . 9 8 3}$ & $\mathbf{0 . 9 8 9}$ & $\mathbf{1}$ & $\mathbf{0 . 9 6 6}$ & $\mathbf{0 . 9 9 7}$ & $\mathbf{0 . 9 8 0}$ \\
Bitterness & 0.012 & 0.718 & $\mathbf{0 . 9 8 8}$ & $\mathbf{0 . 9 9 1}$ & $\mathbf{0 . 9 6 6}$ & $\mathbf{1}$ & $\mathbf{0 . 9 8 3}$ & $\mathbf{0 . 9 9 0}$ \\
Swallowing character & 0.138 & 0.736 & $\mathbf{0 . 9 9 2}$ & $\mathbf{0 . 9 9 8}$ & $\mathbf{0 . 9 9 7}$ & $\mathbf{0 . 9 8 3}$ & $\mathbf{1}$ & $\mathbf{0 . 9 9 0}$ \\
General acceptance & 0.088 & 0.798 & $\mathbf{1 . 0 0 0}$ & $\mathbf{0 . 9 9 4}$ & $\mathbf{0 . 9 8 0}$ & $\mathbf{0 . 9 9 0}$ & $\mathbf{0 . 9 9 0}$ & $\mathbf{1}$ \\
\hline
\end{tabular}

Values indicated in bold are significant at a 0.05 significance level $(p<0.05)$.

the panellists evaluated the colour and odour characters independently compared with other criteria during the sensory analysis. However, taste, sourness, saltiness, bitterness, swallowing character, and general acceptance properties were well correlated with each other. It is noteworthy that the correlation value between the general acceptability and taste criteria was $100 \%$. From this point of view, the criteria of taste and general acceptability were fully correlated, and it can be said that they were completely dependent on each other. The relationship between taste, acidity, saltiness, bitterness, swallowing character, and general acceptability characteristics was found to be statistically significant. It is understood that these variables influence each other in the preference of the panellists because of the high correlation coefficient, such as 0.998 , between the sourness-swallowing character, 0.983 between saltinesstaste, and 0.994 between general acceptance and acidity.

The biplot diagram is commonly used for graphing row and column elements using a single display in PCA [44]. It shows row and column factors from the correspondence analysis of two-way contingency tables and determines interaction in two-way analysis of variance tables. As already mentioned, PCA was employed to explore and visualize the data considering the most relevant responses between variables (colour, odour, saltiness, swallowing character, taste, sourness, bitterness, and general acceptance) and experiments (AA, BB, CC, DD, and $\mathrm{EE}$ ). A biplot display was used and is presented in Figure 4.

The first main component $(F 1)$ and second main component (F2) describe $82.24 \%$ and $13.31 \%$ of the original data information, respectively. In total, $95.55 \%$ of the variations, which is quite a high ratio, almost explain the full range of factors and are clarified in the biplot graph. The narrowing of the angle between the vectors indicates the closeness of the properties between the variables, while expansion of the angle indicates the weakness of the relationship between the properties. Hence, it can be clearly seen that colour is an independent variable from other properties as Table 4 shows that colour has a low correlation with other variables. Experiment EE is located directly above the odour line and shows that odour has the highest score in şalgam EE, as shown in Figure 4, in addition, the saltiness line is nearest to şalgam BB in Figure 4 showing that saltiness has the highest score in experiment BB. Since the correlation coefficient between general acceptability and taste is equal to 1 (Table 4), two variables have been overlapped in the biplot

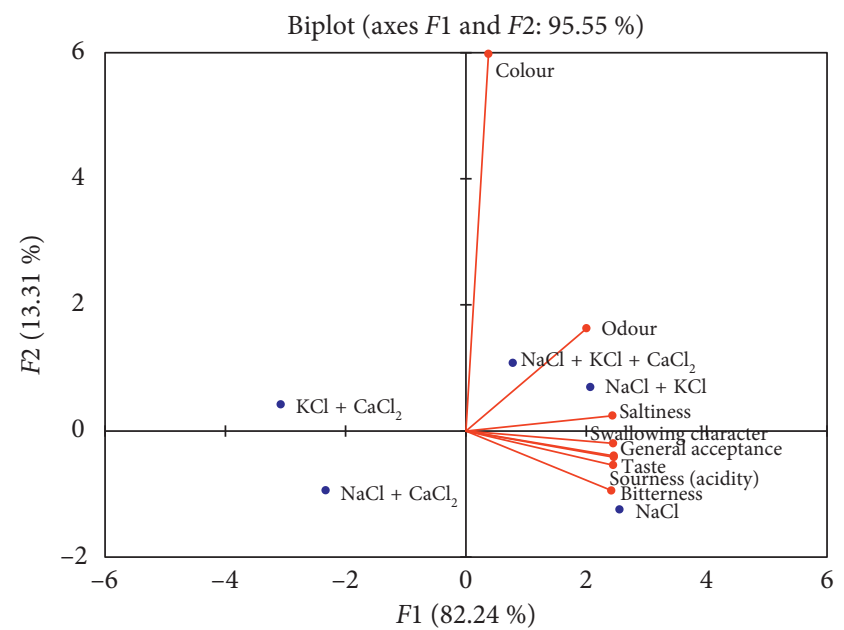

Figure 4: The PCA biplot. Biplot of the simultaneous evaluation of the relationship of scores (different production methods) and loadings (sensory evaluation variables).

chart (Figure 4). With respect to the group of 5 different experiments, the $\mathrm{CC}$ and $\mathrm{DD}$ groups being located on the negative side of the axes show that these two groups tend to be weak and have a negative correlation with the variables. Conversely, groups $\mathrm{AA}, \mathrm{BB}$, and $\mathrm{EE}$ were located on the positive side of the axes and show a close correlation with many variables. As can be seen in Figure $4, \mathrm{AA}(\mathrm{NaCl})$ and $\mathrm{BB}(\mathrm{NaCl}+\mathrm{KCl})$ şalgam groups were found to be closely related with many variables compared with the other groups, and the şalgam produced in these two experiments were the most appreciated in terms of organoleptic character, confirming the results given in Figure 3.

\section{Conclusions}

In this study, the effects of partial and total replacement of $\mathrm{NaCl}$ with $\mathrm{KCl}$ and $\mathrm{CaCl}_{2}$ on the quality of şalgam were investigated. The results obtained shows that all şalgam produced within the scope of the study are compatible with the values specified in the Turkish Şalgam Standard. It was determined that use of different chloride salts in the production of şalgam generally did not cause a significant change in the microbiological and chemical properties of the end product compared with the şalgam produced using $\mathrm{NaCl}$ as the control. However, usage of $\mathrm{KCl}$ promotes the 
growth of LAB significantly during şalgam fermentation. Additionally, utilization of $\mathrm{KCl}$ and $\mathrm{CaCl}_{2}$ salts improved lactic acid formation in şalgam.

The results of sensory analysis demonstrate that şalgam produced using an equal combination of sodium chloride and potassium chloride was favoured by the assessors; therefore, it was determined that the utilization of sodium salt could be reduced by $50 \%$ in the production of şalgam. The other salt, calcium chloride, examined in the study gave a bitter taste to the şalgam, resulting in a product that could not be consumed; hence, $\mathrm{CaCl}_{2}$ was not found to be suitable for the production of şalgam. It is recommended that şalgam juice produced using $\mathrm{NaCl}+\mathrm{KCl}$ salts is more suitable than şalgam produced with the sodium salt, especially for consumers who want to reduce the intake of sodium salts and hypertension patients. Specific studies on this salt are needed in order to determine the optimum $\mathrm{KCl}$ concentration for şalgam production.

\section{Data Availability}

The data used to support the findings of this study are available from the corresponding author upon request.

\section{Conflicts of Interest}

There are no conflicts of interest regarding the publication of this paper.

\section{Acknowledgments}

The authors are grateful for financial support from the Scientific and Technological Research Council of Turkey (TUBITAK-TOVAG 113O818) and Cukurova University Academic Research Projects Unit (Project no. ZF2013YL30 BAP) for their financial support.

\section{References}

[1] H. Erten, B. Ağirman, C. P. Boyaci-Gündüz et al., "Importance of yeasts and lactic acid bacteria in food processing," in Food Processing Strategies for Quality Assessment, A. Malik, Z. Erginkaya, S. Ahmad, and H. Erten, Eds., pp. 351-378, Springer, New York, NY, USA, 2014.

[2] H. Erten, B. Agirman, C. P. Boyaci-Gündüz, and A. Ben Ghorbal, "Regional fermented vegetables and fruits in Europe," in Lactic Acid Fermentation of Fruits and Vegetables, S. Paramithiotis, Ed., pp. 205-235, CRC Press, Boca Raton, FL, USA, 2017.

[3] H. Tanguler and H. Erten, "Chemical and microbiological characteristics of shalgam (şalgam): a traditional Turkish lactic acid fermented beverage," Journal of Food Quality, vol. 35, no. 4, pp. 298-306, 2012.

[4] H. Erten and H. Tanguler, "Shalgam (Şalgam): a traditional Turkish lactic acid fermented beverage based on black carrot," in Handbook of Vegetable Preservation and Processing, Y. H. Hui, E. Ö. Evranuz, H. Erten, G. Bingöl, and M. E. J. Flores, Eds., pp. 841-849, CRC Press, Boca Raton, FL, USA, 2016.

[5] H. Tanguler, E. J. Per Saris, and H. Erten, "Microbial, chemical and sensory properties of shalgams made using different production methods," Journal of the Science of Food and Agriculture, vol. 95, no. 5, pp. 1008-1015, 2015.

[6] H. Tanguler and H. Erten, "Occurrence and growth of lactic acid bacteria species during the fermentation of shalgam (şalgam), a traditional Turkish fermented beverage," LWTFood Science and Technology, vol. 46, no. 1, pp. 36-41, 2012.

[7] N. Turker, S. Aksay, and H. I. Ekiz, "Effect of storage temparature on the stability of anthocyanins of a fermented black carrot (Daucus carota var. L.) beverage: Shalgam," Journal of Agricultural and Food Chemistry, vol. 52, no. 12, pp. 38073813, 2004.

[8] H. Erten, H. Tanguler, and A. Canbas, "A traditional Turkish lactic acid fermented beverage: Shalgam (Salgam)," Food Reviews International, vol. 24, no. 3, pp. 352-359, 2008.

[9] F. J. He, N. R. C. Campbell, and G. A. MacGregor, "Reducing salt intake to prevent hypertension and cardiovascular disease," Revista Panamericana de Salud Pública, vol. 32, no. 4, pp. 293-300, 2012.

[10] WHO, Guideline: Sodium Intake for Adults and Children, 2012, http://www.who.int/nutrition/publications/guidelines/ sodium_intake_printversion.pdf.

[11] I. J. Brown, I. Tzoulaki, V. Candeias, and P. Elliott, "Salt intakes around the world: implications for public health," International Journal of Epidemiology, vol. 38, no. 3, pp. 791-813, 2009.

[12] L. Kloss, J. D. Meyer, L. Graeve, and W. Vetter, "Sodium intake and its reduction by food reformulation in the European Union-a review," NFS Journal, vol. 1, pp. 9-19, 2015.

[13] A. Ursell, Vitamins and Minerals Handbook (Natural Care Handbook), Dorling Kindersley, London, UK, 2001, ISBN: 978-0789471802.

[14] WHO/FAO, Diet, Nutrition and the Prevention of Chronic Diseases, 2003, http://www.who.int/dietphysicalactivity/ publications/trs916/en/gsfao_introduction.pdf.

[15] S. Agarwal, V. L. Fulgoni, L. Spence, and P. Samuel, "Sodium intake status in United States and potential reduction modeling: an NHANES 2007-2010 analysis," Food Science and Nutrition, vol. 3, no. 6, pp. 577-588, 2015.

[16] J. Powles, S. Fahimi, R. Micha et al., "Global, regional and national sodium intakes in 1990 and 2010: a systematic analysis of $24 \mathrm{~h}$ urinary sodium excretion and dietary surveys worldwide," BMJ Open, vol. 3, no. 12, p. e003733, 2013.

[17] USDA (United States Department of Agriculture), Scientific Report of the 2015 Dietary Guidelines Advisory Committee, 2015, https://health.gov/dietaryguidelines/2015-scientific-report/pdfs/ scientific-report-of-the-2015-dietary-guidelines-advisorycommittee.pdf.

[18] J. C. M. Wolkers-Rooijackers, S. M. Thomas, and M. J. R. Nout, "Effects of sodium reduction scenarios on fermentation and quality of sauerkraut," LWT-Food Science and Technology, vol. 54, no. 2, pp. 383-388, 2013.

[19] S. Bonatsou, V. Iliopoulos, A. Mallouchos et al., "Effect of osmotic dehydration of olives as pre-fermentation treatment and partial substitution of sodium chloride by monosodium glutamate in the fermentation profile of Kalamata natural black olives," Food Microbiology, vol. 63, pp. 72-83, 2017.

[20] J. Bautista-Gallego, F. N. Arroya-Lopez, V. Romero-Gil, F. Rodriguez-Gomez, P. Garcia-Garcia, and A. GarridoFernandez, "Fermentation profile of green Spanish-style Manzanilla olives according to NaCI content in brine," Food Microbiology, vol. 49, pp. 56-64, 2015.

[21] H. L. A. Silva, C. F. Balthazar, R. S. Rocha et al., "Sodium reduction and flavor enhancers addition: is there an impact on the availability of minerals from probiotic Prato cheese?," LWT-Food Science and Technology, vol. 93, pp. 287-292, 2018. 
[22] S. Leventdurur, S. Sert-Aydin, C. P. Boyaci-Gündüz et al., "Yeast biota of naturally fermented black olives in different brines made from $c v$. Gemlik grown in various districts of the Cukurova region of Turkey," Yeast, vol. 33, no. 7, pp. 289-301, 2016.

[23] D. J. McMahon, C. J. Oberg, M. A. Drake et al., "Effect of sodium, potassium, magnesium and calcium salt cations on $\mathrm{pH}$, proteolysis, organic acids and microbial populations during storage of full-fat Cheddar cheese," Journal of Dairy Science, vol. 97, no. 8, pp. 4780-4798, 2014.

[24] E. Z. Panagou, O. Hondrodimou, A. Mallouchos, and G. J. E. Nychas, "A study on the implications of NaCI reduction in the fermentation profile of Conservolea natural black olives," Food Microbiology, vol. 28, no. 7, pp. 1301-1307, 2011.

[25] P. Zinno, B. Guantario, G. Perozzi, G. Pastore, and C. Devirgiliis, "Impact of $\mathrm{NaCl}$ reduction on lactic acid bacteria during fermentation of Nocellara del Belice table olives," Food Microbiology, vol. 63, pp. 239-247, 2017.

[26] S. Bae, G. H. Fleet, and G. M. Heard, "Lactic acid bacteria associated with wine grapes from several Australian vineyards," Journal of Applied Microbiology, vol. 100, no. 4, pp. 712-727, 2006.

[27] P. Coulin, Z. Farah, J. Assavo, H. Spillmann, and Z. Puhan, "Characterization of the microflora of attieke, a fermented cassava product, during traditional small-scale preperation," International Journal of Food Microbiology, vol. 106, no. 2, pp. 131-136, 2006.

[28] I. Campbell, "Culture, storage, isolation and identification of yeasts," in Yeast-A Practical Approach, I. Campbell and F. G. Priest, Eds., pp. 1-11, Chapman and Hall, London, UK, 1988.

[29] G. Vieira-Dalodé, L. Jespersen, J. Hounhouigan, P. L. Moller, C. M. Nago, and M. Jakobsen, "Lactic acid bacteria and yeasts associated with gowé production from sorghum in Bénin," Journal of Applied Microbiology, vol. 103, no. 2, pp. 342-349, 2007.

[30] TSE (Turkish Standardization Institute), TS 11149 Standard of Şalgam Beverage, TSE, Ankara, Turkey, 2016.

[31] S. S. Nielsen, "Sodium determination using ion selective electrodes, Mohr titration and test strips," in Food Analysis Laboratory Manual, S. S. Nielsen, Ed., pp. 75-85, Springer, New York, NY, USA, 2010.

[32] A. Amrane and Y. Prigent, "Behaviour of the yeast Kluyveromyces marxianus var. marxianus during its autolysis," Antonie Van Leeuwenhoek, vol. 69, no. 3, pp. 267-272, 1996.

[33] T. K. Ghose, "Measurement of cellulase activities," Pure and Applied Chemistry, vol. 59, no. 2, pp. 257-268, 1987.

[34] AOAC, Official Methods of Analysis of the Association of Official Analytical Chemists, Association of Official Analytical Chemists Inc., Arlington, VA, USA, 15th edition, 1990.

[35] J. M. Barillere and P. Benard, "Exemples d'interpretation de résultats de dégustation," OENO One, vol. 20, no. 3, pp. 137-154, 1986.

[36] K. R. Gabriel, "The biplot graphic display matrices with application to principal component analysis," Biometrika, vol. 58, no. 3, pp. 453-467, 1971.

[37] K. Özdamar, Paket programlar ile istatiksel veri analizi, Nisan Kitabevi, Ankara, 2015, in Turkish, ISBN: 97-8-975642851-1.

[38] H. Tanguler, "Identification of predominant lactic acid bacteria isolated from shalgam beverage and improvement of its production technique," Doctor of Philosophy thesis, Cukurova University, Adana, Turkey, 2010.
[39] D. Utus, "The effect of black carrot (Daucus carota) size usage on the quality of shalgam production," Master of Science Thesis, Cukurova University, Adana, Turkey, 2008.

[40] M. Arici, "Microbiological and chemical properties of a drink called shalgam," Ernahrungs-Umschau, vol. 51, pp. 10-11, 2004.

[41] H. Tanguler, G. Gunes, and H. Erten, "Influence of addition of different amounts of black carrot (Daucus carota) on shalgam quality," Journal of Food, Agriculture and Environment, vol. 12, no. 2, pp. 60-65, 2014.

[42] N. Demir, K. S. Bahceci, and J. Acar, "The effects of different initial Lactobacillus plantarum concentrations on some properties of fermented carrot juice," Journal of Food Processing and Preservation, vol. 30, no. 3, pp. 352-363, 2006.

[43] V. Marsilio, C. Campestre, B. Lanza, M. De Angelis, and F. Russi, "Sensory analysis of green table olives fermented in different saline solutions," Acta Horticulturae, vol. 586, pp. 617-620, 2002.

[44] K. F. M. Pasqualoto, R. F. Teofilo, M. Guterres, F. S. Pereira, and M. M. C. Ferreira, "A study of physicochemical and biopharmaceutical properties of Amoxicillin tablets using full factorial design and PCA biplot," Analytica Chimica Acta, vol. 595, no. 1-2, pp. 216-220, 2007. 


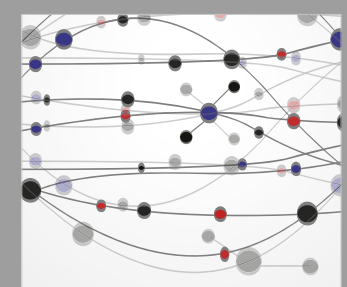

The Scientific World Journal
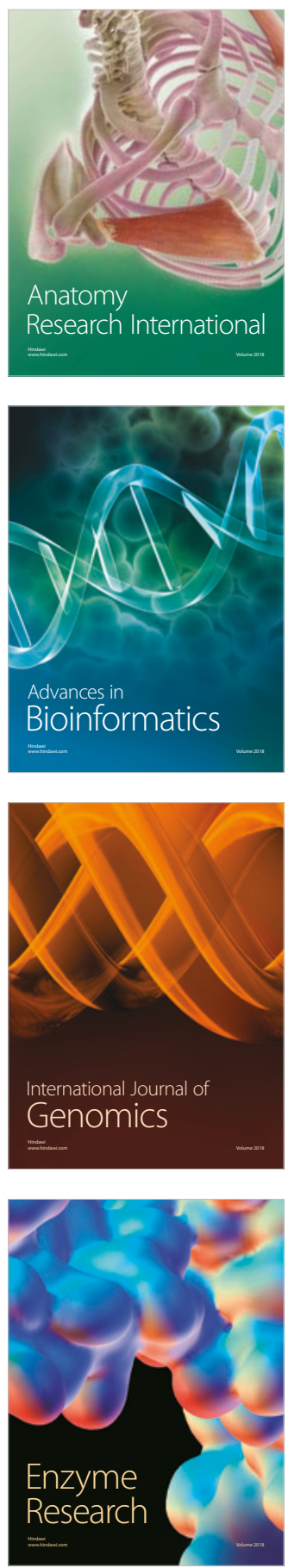
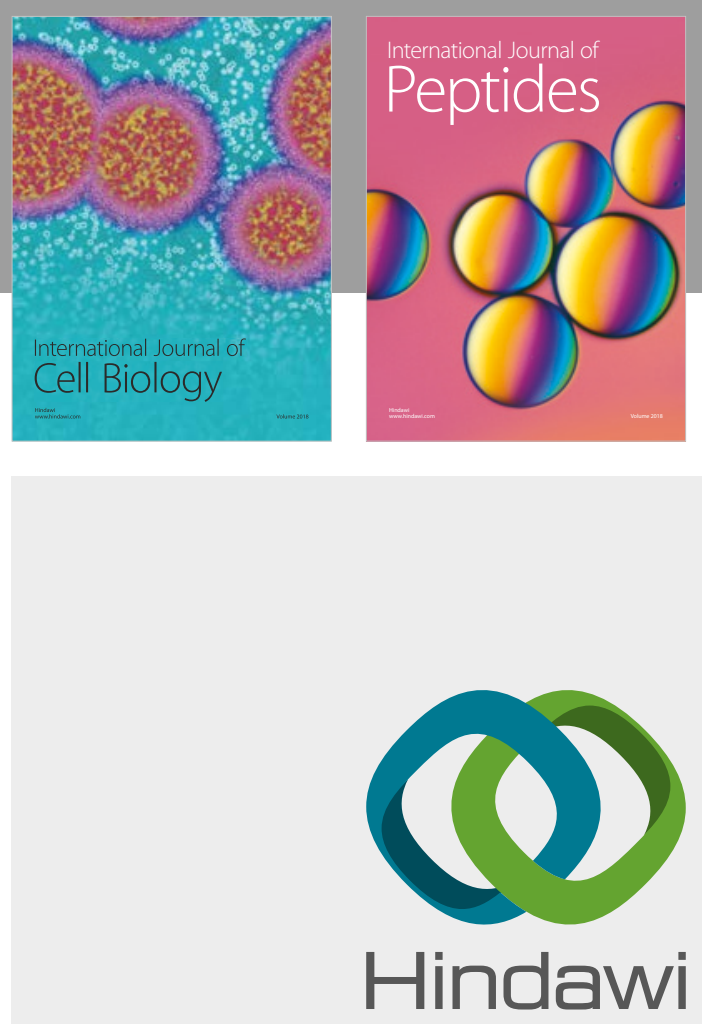

Submit your manuscripts at

www.hindawi.com
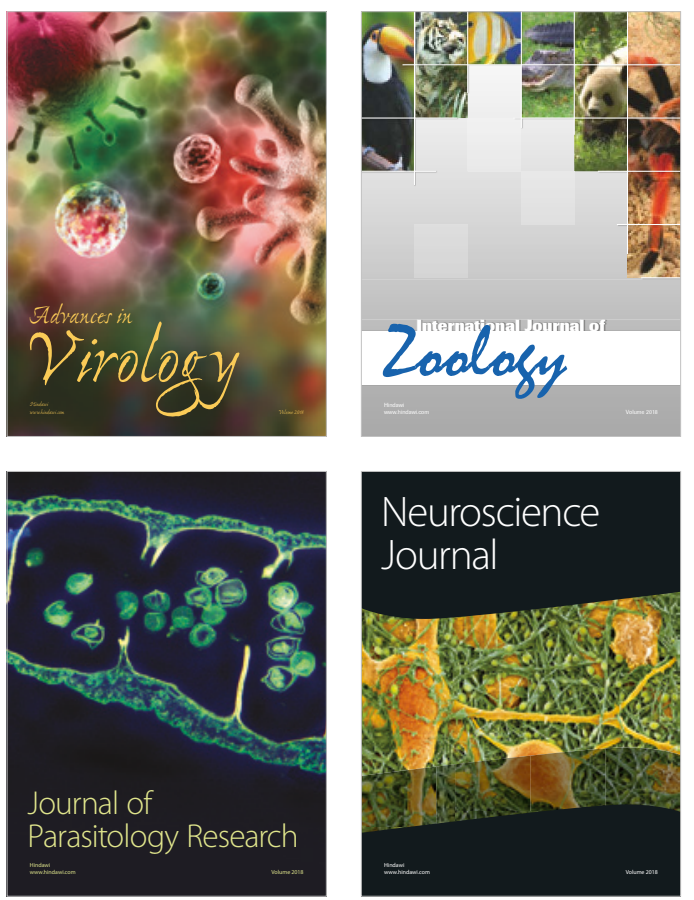
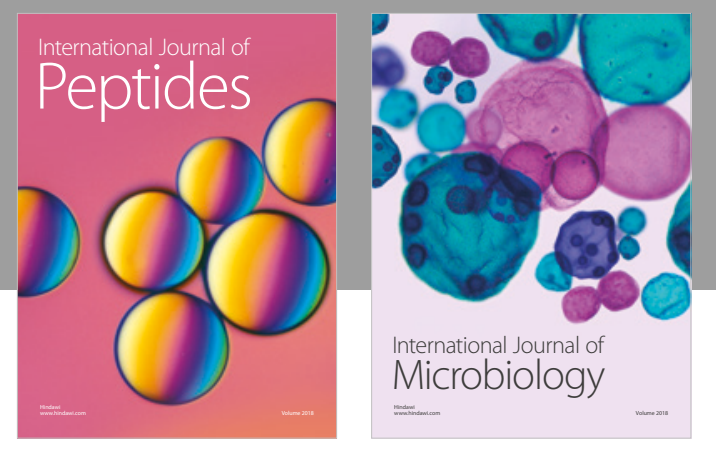

nternational Journal of Microbiology
Journal of
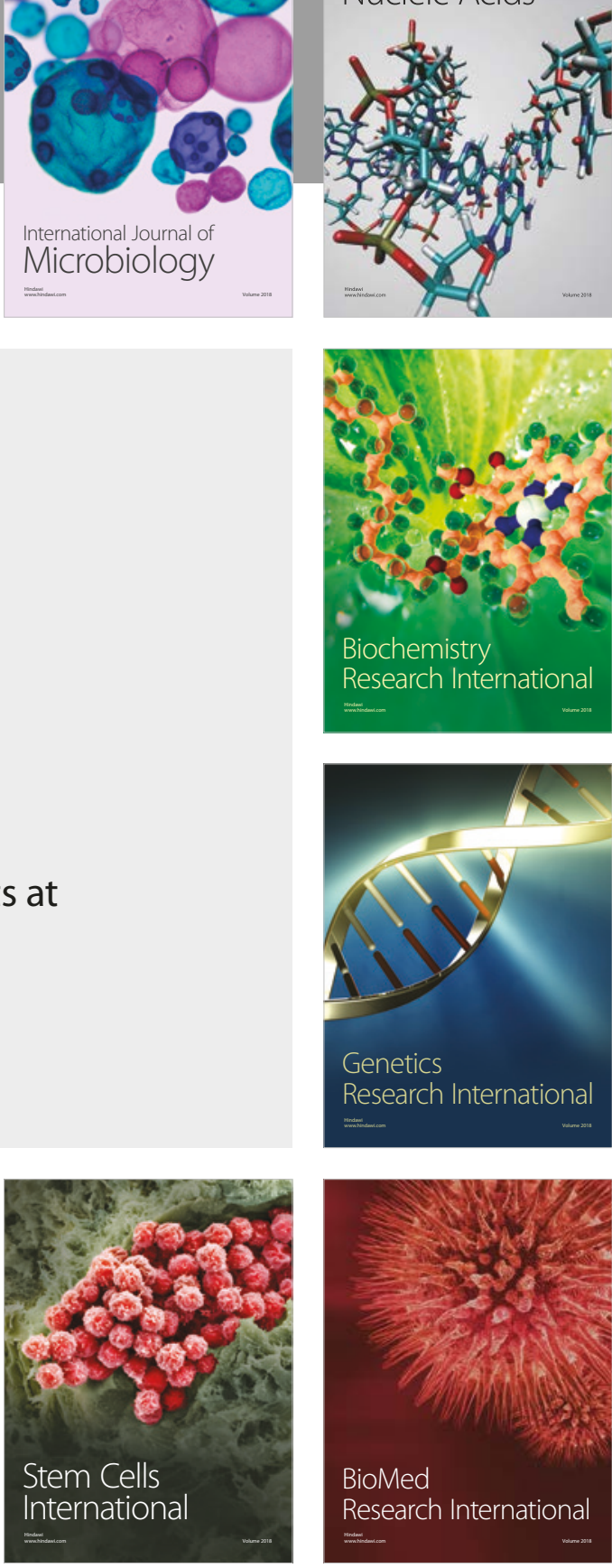
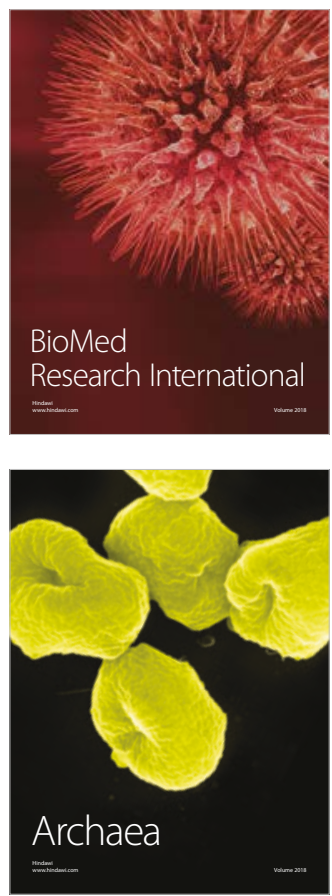